\title{
A multiplex real-time PCR method for differentiation of beef, buffalo meat and pork
}

\author{
Tan M. $\operatorname{Tran}^{1 *}, \&$ Tuan N. Nguyen ${ }^{2}$ \\ ${ }^{1}$ Regional Animal Health Office No.6, Ho Chi Minh City, Vietnam \\ ${ }^{2}$ Faculty of Animal Science and Veterinary Medicine, Nong Lam University, Ho Chi Minh City, Vietnam
}

ARTICLE INFO
Research Paper
Received: May 15, 2018
Revised: July 28, 2018
Accepted: August 14, 2018
Keywords
Beef
Buffalo
DNA
Multiplex real-time PCR
Pork
*Corresponding author
Tran Minh Tan
Email: tranminhtan06@gmail.com

Cited as: Tran, T. M., \& Nguyen, T. N. (2019). A multiplex real-time PCR method for differentiation of beef, buffalo meat and pork. The Journal of Agriculture and Development 18(1), 63-71.

\section{ABSTRACT}

The objective of this study was to optimize a multiplex real-time PCR protocol for detection of DNA of beef, buffalo meat and pork, serving for food authenticity. The optimized concentrations were 200 $\mathrm{nM}$ primer and $100 \mathrm{nM}$ specific probe for beef/buffalo meat, and $300 \mathrm{nM}$ primer and $150 \mathrm{nM}$ probe for pork. The amplification was performed using initial denaturation at $50^{\circ} \mathrm{C}$ for $2 \mathrm{~min}, 95^{\circ} \mathrm{C}$ for 2 min, followed by 45 cycles of denaturation at $95^{\circ} \mathrm{C}$ for $15 \mathrm{sec}$, and annealing and extension at $60^{\circ} \mathrm{C}$ for $40 \mathrm{sec}$. This protocol had high sensitivity and specificity. The detection limit of this method was found to be $0.1 \%$ in raw and heat-treated meat mix $\left(80-121^{\circ} \mathrm{C} / 15\right.$ min) or $0.005 \mathrm{ng} \mathrm{DNA} /$ reaction. The protocol of testing was applied for the commercial products both fresh and processed meats. The results demonstrated that $50 \%$ of raw beef sample $(6 / 12)$ weren't found beef DNA. Eight of twelve beef sausage samples $(66.67 \%)$ contained buffalo DNA. Beef DNA were found in all 12 samples of beef meatballs, but eight out of the 12 meatball samples were confirmed to have buffalo DNA $(66.67 \%)$ and two out of the 12 meatball samples $(16.67 \%)$ also contained porcine DNA. 


\title{
Phân biệt thịt bò, trâu, heo bằng kỹ thuật multiplex real-time PCR
}

\author{
Trần Minh Tấn ${ }^{1 *} \&$ Nguyễn Ngọc Tuân ${ }^{2}$ \\ ${ }^{1}$ Chi Cục Thú Y Vùng VI, TP. Hồ Chí Minh \\ ${ }^{2}$ Khoa Chăn Nuôi Thú Y, Trường Đại Học Nông Lâm TP. Hồ Chí Minh, TP. Hồ Chí Minh
}

\section{THÔNG TIN BÀI BÁO}

Bài báo khoa học

Ngày nhận: 15/05/2018

Ngày chỉnh sửa: 28/07/2018

Ngày chấp nhận: 14/08/2018

\section{Từ khóa}

Bò

DNA

Heo

Multiplex real-time PCR

Trâu

*Tác giả liên hệ

Trần Minh Tấn

Email: tranminhtan06@gmail.com

\section{TÓM TẮT}

Mục tiêu của bài báo là tối ưu quy trình multiplex real-time PCR nhận diện DNA bò, trâu, heo, từ đó ứng dụng quy trình để phân biệt nhanh, chính xác loại thịt và sản phẩm chế biến từ thịt bò, heo, trâu trong gian lận thượng mại. Quy trình tối ưu có nồng độ mồi $200 \mathrm{nM}$ và đoạn dò $100 \mathrm{nM}$ (bò và trâu), nồng độ mồi $300 \mathrm{nM}$ và đoạn dò $150 \mathrm{nM}$ (heo); chu trình nhiệt $50^{\circ} \mathrm{C} / 2$ phút, $95^{\circ} \mathrm{C} / 2$ phút, 45 chu kỳ gồm biến tính ở $95^{\circ} \mathrm{C} / 15$ giây và bắt cặp - kéo dài ở $60^{\circ} \mathrm{C} / 40$ giây. Quy trình có độ nhạy và độ đặc hiệu cao, giới hạn phát hiện của phương pháp đối với hỗn hợp mẫu thịt tươi và thịt đã xử lý nhiệt (80 - $120^{\circ} \mathrm{C} / 15$ phút) là $0,1 \%$ theo khối lượng hoặc 0,005 ng DNA/phản ứng. Áp dụng quy trình để kiểm tra thịt tươi và sản phẩm thịt chế biến trên thị trường đã phát hiện sự gian lận. Kết quả nghiên cứu sơ bộ cho thấy $50 \%$ (6/12) mẫu thịt bò tươi không phát hiện được DNA bò. Có $66,67 \%$ (8/12) mẫu xúc xích bò chứa thịt trâu trong sản phẩm. Tất cả 12 mẫu bò viên được kiểm tra đều phát hiện có chứa DNA bò, nhưng $66,67 \%$ mẫu lẫn thị trâu và $16,67 \%$ mẫu lẫn thịt heo.

\section{1. Đặt Vấn Đề}

Việc xác định loài trong sản phẩm thịt là một lĩnh vực được phát triển nhanh chóng do có liên quan đến sức khỏe người tiêu dùng, tôn giáo và gian lận thương mại. Trên thị trường, nhiều sản phẩm thịt tươi và sản phẩm thịt chế biến không ghi đúng nhãn hiệu, thành phần các loại thịt để gian lận, lừa dối người tiêu dùng nhằm thu lợi bất chính. Người Ai Cập và một số người ở châu Âu thích sử dụng thịt trâu để thay thế thịt bò do lo sợ bệnh bò điên - BSE (Sakaridis \& ctv., 2013). Việt Nam cũng như một số nước không cho phép nhập bột thịt xương có nguồn gốc từ bò ở các nước và vùng lãnh thổ có bệnh BSE để làm nguyên liệu cho thức ăn gia súc. Một số các báo cáo đã cho thấy có sự gian lận trong thương mại gây ảnh hưởng đến chất lượng sản phẩm cũng như sức khỏe người tiêu dùng. Theo Ayaz \& ctv. (2006), khoảng $22 \%$ thịt và sản phẩm thịt chế biến ở Thổ Nhĩ Kỳ chứa loại thịt không được ghi trên nhãn.
Ở Trung Quốc, cảnh sát đã thu giữ hơn 20 tấn thịt bò giả làm từ thịt heo được xử lý với hóa chất (Jeanette, 2013). Tháng 02/2016, Chi cục Thú y TP. Hồ Chí Minh đã bắt quả tang một công ty ngâm thịt heo nái với hóa chất và huyết bò để làm giả thịt bò (Hoang, 2016). Tháng 07/2016, Trung tâm giám định pháp y (Sở Y tế TP.HCM) thông báo kết quả giám định bò viên của một công ty (quận Bình Tân) cho thấy mẫu bò viên nhãn hiệu GoGo chỉ có DNA cá, không tìm thấy DNA bò và mẫu bò viên nhãn hiệu Merlion chỉ có DNA trâu và cá không có DNA bò (NCVTV24, 2016). Như vậy, thịt bò và sản phẩm từ thịt bò có giá trị kinh tế cao đã bị làm giả từ thịt trâu, thit heo.

Ngày nay, có nhiều phương pháp phân biệt các loại thịt và sản phẩm chế biến từ thịt. Phương pháp phát hiện dựa vào protein như điện di, miễn dịch, sắc ký. Nhược điểm của phương pháp này lại cho kết quả chậm hoặc không thể áp dụng với sản phẩm thịt đã xử lý nhiệt độ cao. Phương 
pháp dựa vào DNA như khuếch đại ngẫu nhiên đa hình DNA-RAPD (Random Amplified Polymorphic DNA), PCR đặc trưng cho loài (speciesspecific $\mathrm{PCR}$ ) thường được sử dụng nhiều hơn để xác định loài như thịt bò (Mane \& ctv., 2012), thịt trâu (Girish \& ctv., 2013), thịt heo (Erwanto \& ctv., 2014). Tuy nhiên, các phương pháp này chủ yếu phát hiện một loài duy nhất, và đoạn DNA mục tiêu kích thước lớn nên dễ bị hư hỏng bởi nhiệt khi chế biến. Hậu quả là làm cho các kỹ thuật này ít tin cậy và đắt tiền hơn (Ali \& ctv., 2015).

Với sự phát triển của sinh học phân tử, kỹ thuật này cho phép phát hiện nhiều gene đích của nhiều loài khác nhau trong cùng một sản phẩm thịt, đồng thời tăng độ tin cậy của phản ứng do sử dụng các đoạn dò (probe) đặc hiệu và rút ngắn thời gian thu kết quả (Ali \& ctv., 2014) Tuy nhiên, đến thời điểm hiện tại, chưa có nhiều công trình ứng dụng multiplex real-time PCR phát hiện cùng lúc thịt bò, trâu, heo từ thịt tươi hoặc sản phẩm thịt chế biến. Đây là ba loại thịt mà người tiêu dùng khó phân biệt về mặt cảm quan, người sản xuất có thể giả nhãn hiệu và thành phần của sản phẩm. Vì vậy, mục tiêu của bài báo là tối ưu quy trình phân biệt thịt bò, trâu, heo trong cùng một phản ứng multiplex real-time $\mathrm{PCR}$ nhằm phân biệt nhanh và chính xác loại thịt và sản phẩm chế biến từ thịt bò, heo, trâu khi chứng minh gian lận thượng mại; kiểm soát thức ăn gia súc có thành phần bò từ vùng bị bệnh bò điên nhập khẩu vào Việt Nam.

\section{Vật Liệu và Phương Pháp Nghiên Cứu}

\subsection{Chuẩn bi mẫu}

Hai mươi bốn mẫu thịt tươi (bò, heo, trâu) được thu thập từ một số lò mổ và mẫu thịt kiểm dịch nhập khẩu ở TP. Hồ Chí Minh. Mẫu được bảo quản lạnh đông $-20^{\circ} \mathrm{C}$ đến khi tiến hành thử nghiệm. Mỗi mẫu thịt tươi được lấy khoảng 100 $\mathrm{g}$ cho vào túi nylon sạch, dán nhãn riêng. $\mathrm{Ba}$ mươi mẫu thịt từ 15 loài động vật và thủy sản khác được thu thập để kiểm tra độ nhạy, độ đặc hiệu (02 mẫu mỗi loài). Bao gồm nhóm thú ăn cỏ (cừu, dê, ngựa), nhóm gia cầm (gà, cút, vịt, ngan), nhóm thú ăn thịt (chó, mèo), nhóm thú gậm nhấm (thỏ, chuột) và nhóm hải sản (tôm, cá). Ngoài ra, đậu nành cũng được kiểm tra đánh giá độ nhạy, độ đặc hiệu vì đây là thành phần thường được thêm vào trong chế biến xúc xích thịt. Khảo sát còn thu thập 12 mẫu thịt bò tươi tại các thớt thịt lẻ; xúc xích bò (12 mẫu) và bò viên (12 mẫu) từ siêu thị, cửa hàng thực phẩm tại TP.HCM để kiểm tra thành phần thịt ghi trên nhãn sản phẩm.

\subsection{Chiết tách DNA}

$25 \mathrm{mg}$ sản phẩm cho mỗi mẫu được tách chiết DNA bằng bộ kít DNeasy blood and tissue (Qiagen, Đức Cat.No 69606). Độ tinh sạch DNA được kiểm tra bằng cách đo mật độ quang (OD) ở bước sóng $260 \mathrm{~nm}$ và $280 \mathrm{~nm}$ bằng máy quang phổ (Nanodrop 2000). Mẫu DNA tách chiết được tinh sạch khi có tỷ số $\mathrm{OD}_{260} / \mathrm{OD}_{280}$ đạt từ $1,8-2,0$. Nồng độ DNA tổng số $(\mathrm{ng} / \mu \mathrm{L})$ được ước lượng theo công thức: $\mathrm{OD}_{260} \times 50 \times$ độ pha loãng.

\section{3. Đoạn mồi và đoạn dò}

Trình tự đoạn mồi và đoạn dò theo Bảng 1 .

\subsection{Quy trình multiplex real-time PCR}

Mỗi ống phản ứng $25 \mu \mathrm{l}$ PCR chứa mastermix $5 \mu \mathrm{L}$ DNA, nồng độ mồi theo Bảng 1. Sử dụng bộ kít Platinum ${ }^{\circledR}$ Quantitative PCR SuperMixUDG(Invitrogen, Cat.No 11730-017). Phản ứng real-time $\mathrm{PCR}$ được thực hiện bằng máy Agilent Stratagene $\mathrm{Mx} 3005 \mathrm{P}$ Systems, ở $50^{\circ} \mathrm{C} / 2$ phút, $95^{0} \mathrm{C} / 2$ phút, 45 chu kỳ biến tính tại $95^{\circ} \mathrm{C} / 15$ giây và bắt cặp - kéo dài ở $60^{\circ} \mathrm{C} / 40$ giây.

Tối ưu hóa phản ứng simplex để khẳng định nồng độ mồi thích hợp cho mỗi loài và điều kiện phòng thí nghiệm. DNA mỗi loài được pha loãng bậc 10 từ mẫu gốc để chạy đường chuẩn. Có hai thông số thể hiện tính ồn định của đường chuẩn (Pham, 2009). Thông số đầu tiên là hệ số tương quan $\mathrm{R}^{2}$. Trị số $\mathrm{R}^{2}$ phải đạt trên hoặc bằng $(\geq)$ 0,99 . Có nghĩa là đường biểu diễn chuẩn phải đạt độ tuyến tính cao. Thông số thứ hai là hiệu quả PCR được gọi là E\% (PCR efficiency). PCR đạt hiệu quả lý tưởng khi sau mỗi chu kỳ cường độ huỳnh quang trong một ống phản ứng tăng gấp đôi. Hai ống phản ứng có số lượng DNA đích ban đầu cách nhau hệ số pha loãng $\mathrm{A}$, thì hai đường biểu diễn khuếch đại sẽ cách nhau $n$ chu kỳ với cường độ huỳnh quang của hai ống sẽ cách nhau một hệ số pha loãng $\mathrm{A}=2^{\mathrm{n}}$. Hiệu quả PCR chấp nhận khi $\mathrm{E} \%$ khoảng $90 \%$ đến $110 \%$. Với công thức $\mathrm{E} \%=(\mathrm{E}-1) \times 100 \% ; \mathrm{E}=10^{-1 / \text { slope }}$, trong đó với slope là độ dốc đường chuẩn. Đường biểu diễn chuẩn lý tưởng khi slope bằng $-3,32$. Độ dốc này được phép dao động khoảng $-3,58$ đến $-3,1$. 


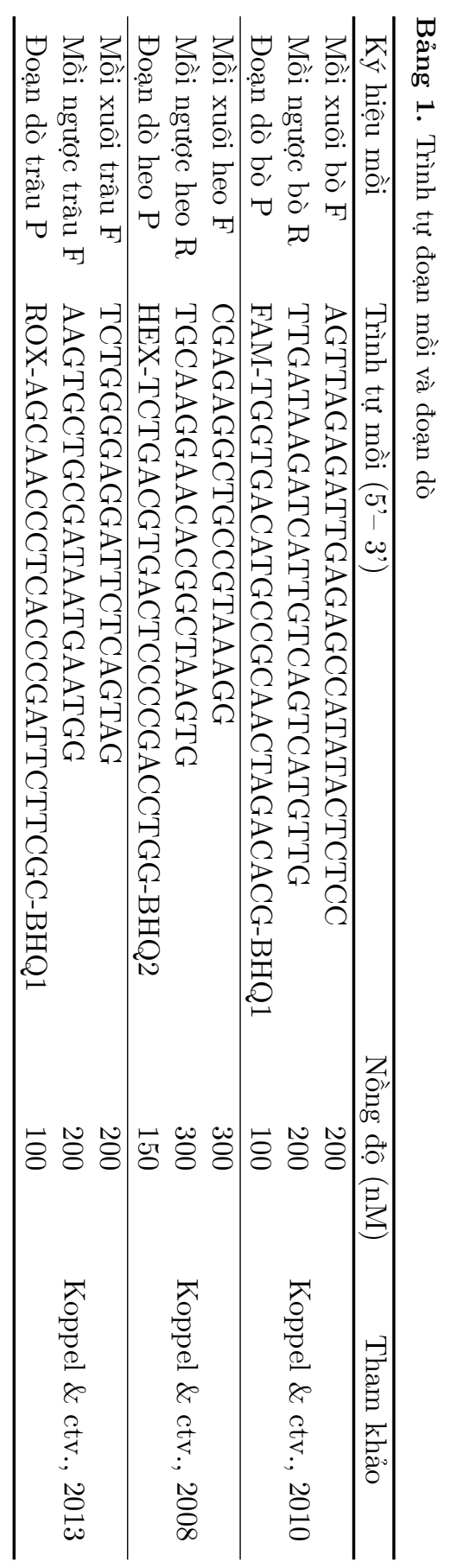

Sau khi thực hiện real-time PCR đơn, hai tổ hợp mastermix mỗi loài được chọn. Ba loài: bò, heo và trâu với 2 tổ hợp mastermix đơn mỗi loài tạo thành 8 tổ hợp master mix đa mồi để chạy realtime PCR. Tổ hợp master mix được chọn khi có đường khếch đại huỳnh quang xuất hiện sớm (giá trị $\mathrm{Ct}$ nhỏ) và giai đoạn bình nguyên ổn định. Tổ hợp mồi thích hợp được chọn có nồng độ theo Bảng 1.

\section{5. Độ đặc hiệu, độ nhạy}

Mẫu thịt bò đối chứng dương được lấy từ nhiều nguồn gốc khác nhau như bò ta vàng trong nước, bò nhập khẩu từ Mỹ, Úc, Nhật,... Thịt trâu cũng được lấy từ trâu trong nước và trâu từ Ân Độ. Thịt heo được lấy từ giống heo địa phương, heo rừng, heo ngoại lai và thịt heo nhập khẩu. Mẫu âm tính được lấy từ loài khác như mẫu thịt cừu, dê, ngựa, gà, cút, vịt, ngan, chó, mèo, thỏ, chuột, tôm, cá tra, cá ngừ và bột đậu nành. Độ nhạy là tỷ lệ \% dương tính bằng phương pháp chẩn đoán trên tổng số mẫu dương tính thật sự. Độ đặc hiệu là tỷ lệ \% âm tính bằng phương pháp chẩn.

\subsection{Giới hạn phát hiện (LOD)}

Để xác định giới hạn phát hiện của phương pháp, DNA tách chiết được pha loãng bậc 10 với nồng độ giảm dần từ $10 \mathrm{ng} / \mu \mathrm{L}$ đến $0,0001 \mathrm{ng} / \mu \mathrm{L}$. Sau đó, phản ứng multiplex real-time PCR được thực hiện để tìm nồng độ thấp nhất có thể phát hiện được DNA của bò, trâu và heo.

\subsection{Xử lý số liệu}

Số liệu thu thập được xử lý bằng Excel.

\section{Kết Quả và Thảo Luận}

\subsection{Tách chiết DNA}

Tất cả 56 mẫu được tách chiết DNA. Nồng độ DNA thu được từ 40,6 - 94,6 ng/ $\mu \mathrm{L}$ và tỷ số $\mathrm{OD}_{260} / \mathrm{OD}_{280}$ nằm trong khoảng $1,8-2,0$. Như vậy, DNA đã được tinh sạch tốt, sẵn sàng sử dụng cho phản ứng real-time PCR.

\subsection{Quy trình multiplex real-time PCR}

Hệ số tương quan $\mathrm{R}^{2}$ đối với DNA bò là 0,992 với heo là 0,990 và trâu là 0,995 (Hình 1$)$. Những hệ số tương quan này hoàn toàn phù hợp với giới 
hạn cho phép $\left(\mathrm{R}^{2} \geq 0,99\right)$. Hệ số này cho thấy các giá trị Ct tại các điểm pha loãng bậc 10 có độ tuyến tính cao, thao tác pha loãng mẫu, thao tác pipet hút đúng lượng thể tích cần sử dụng. Một tiêu chí khác để đánh giá phản ứng real-time PCR là hiệu quả phản ứng $\mathrm{PCR}(\mathrm{E} \%)$. Khoảng giới hạn cho phép của E\% trong khoảng 90 - 110\%. Giá trị $\mathrm{E} \%$ đạt được trong phản ứng real-time $\mathrm{PCR}$ đa mồi từ 96,2 - 104,3\% (Hình 1) nằm trong giới hạn cho phép. Mặt khác, độ dốc (slope) từ -3,417 đến - 3,222 là phù hợp với khoảng giới hạn từ -3,58 đến $-3,10$.
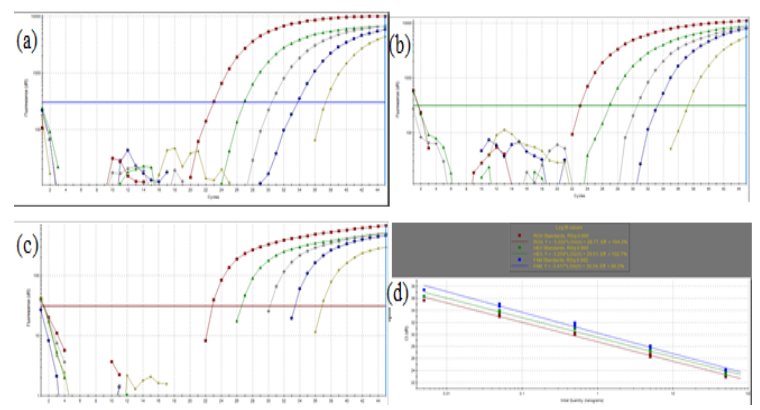

Hình 1. Đường khuếch đại của DNA bò (a), heo (b) và trâu (c) Đường chuẩn DNA bò, heo, trâu (d).

Độ đặc hiệu của phản ứng được đánh giá trên mẫu thịt của 3 loài mục tiêu và những loài khác. Tổng số mẫu thực hiện là 56 mẫu. Trong đó có 8 mẫu bò, 8 mẫu heo, 8 mẫu trâu và 30 mẫu của 15 loài khác gồm cừu, dê, ngựa, gà, cút, vịt, ngan, chó, mèo, thỏ, chuột, tôm, cá tra, cá ngừ và 2 mẫu đậu nành. Tín hiệu huỳnh quang màu FAM chỉ được ghi nhận trên những mẫu có nguồn gốc từ bò. Những mẫu có nguồn gốc từ heo, trâu và các loài khác không ghi nhận được tín hiệu màu FAM của bò. Tương tự, màu HEX chỉ được ghi nhận trên những mẫu có nguồn gốc từ heo và màu ROX chỉ được ghi nhận trên những mẫu có nguồn gốc từ trâu. Các mẫu bò, heo, trâu đều được phát hiện trong cùng một phản ứng multiplex realtime và không có phản ứng chéo giữa các loài khác nhau. Độ nhạy và độ đặc hiệu của phản ứng đều đạt $100 \%$ đối với bò, heo và trâu.

\subsection{Giới hạn phát hiện của DNA}

Giá trị $\mathrm{Ct}$ và độ lệch chuẩn tương đối (relative standard deviation: RSD) được thể hiện trong Bảng 2. Giá trị RSD biến thiên thấp cho thấy phản ứng multiplex real-time PCR có tính ổn định cao ở các nồng độ DNA khác nhau và ở những lần chạy kiểm tra khác nhau. Tại nồng độ
0,005 ng/phản ứng, giá trị Ct trung bình của mẫu DNA bò là $36,72 \pm 0,240$. Ct mẫu heo và trâu ở nồng độ này lần lượt $37,75 \pm 0,125$ và $37,71 \pm$ 0,100. Ở nồng độ pha loãng tiếp theo sau đó cho kết quả âm tính với cả ba loài vì không ghi nhận được tín hiệu huỳnh quang, RSD ở tất cả nồng độ pha loãng này có giá trị nhỏ hơn 1,0 (0,08 $0,886)$. Như vậy, giới hạn phát hiện DNA của quy trình là $0,005 \mathrm{ng} / \mathrm{phản}$ ứng.

\section{4. Ứng dụng giới hạn phát hiện trong hỗn hợp thịt tươi và thịt xử lý nhiệt}

Trong thí nghiệm này, thịt gà được sử dụng làm nền mẫu để thêm các loại thịt bò, heo, trâu tạo thành hỗn hợp có tỷ lệ khác nhau, giảm dần từ $32,0 \%$ dến $0,1 \%$. Sở dĩ thí nghiệm chọn tỷ lệ phối trộn thấp nhất là $0,1 \%$ vì trong gian lận thương mại nếu dưới mức tỷ lệ này sẽ không đem lại hiệu quả kinh tế, giá thành sản phẩm giảm không đáng kể. Kết quả ở Bảng 3 cho thấy không có sự khác biệt lớn giá trị Ct giữa mẫu đã xử lý nhiệt và mẫu thịt tươi. Và ở tỷ lệ $0,1 \%$ về trọng lượng, giá trị $\mathrm{Ct}$ của mẫu thịt tươi và thịt đã xử lý nhiệt nằm trong khoảng 29,02 đến 34,61. Như vậy, bò, heo, trâu đều được phát hiện ở mức $0,1 \%$ trọng lượng trong hỗn hợp thịt tươi và thịt xử lý nhiệt.

\section{5. Áp dụng để kiểm tra một số mẫu thịt tươi và thịt chế biến lưu hành trên thị trường}

\subsubsection{Mẫu thịt tươi}

Trong 12 mẫu thịt bò được kiểm tra, kết quả nhận diện được 06 mẫu là thịt bò, 02 mẫu là thịt trâu và 04 mẫu hiện diện vừa thịt heo và thịt trâu (Bảng 4). Bốn mẫu này là những mẫu thịt đã được người bán thái mỏng trước khi được thu thập mẫu. Có lẽ người bán thịt đã pha lẫn thịt trâu với thịt heo để tạo hương vị và màu sắc thịt bò nhằm đánh lừa người tiêu dùng. Như vậy, một nửa số mẫu thịt bò tươi được kiểm tra đã có gian lận, làm giả thịt bò từ thịt heo và thịt trâu.

\subsubsection{Mẫu xúc xích}

Trong 12 mẫu được kiểm tra, tất cả đều phát hiện được thành phần heo như công bố trên bao bì của nhà sản xuất (Bảng 5 ). Tuy nhiên, thịt trâu đã được phát hiện tất cả 8 mẫu của công ty $A$ và $B$. Đó là thành phần thịt mà 2 công ty đều không công bố trong nhãn sản phẩm. Thịt 


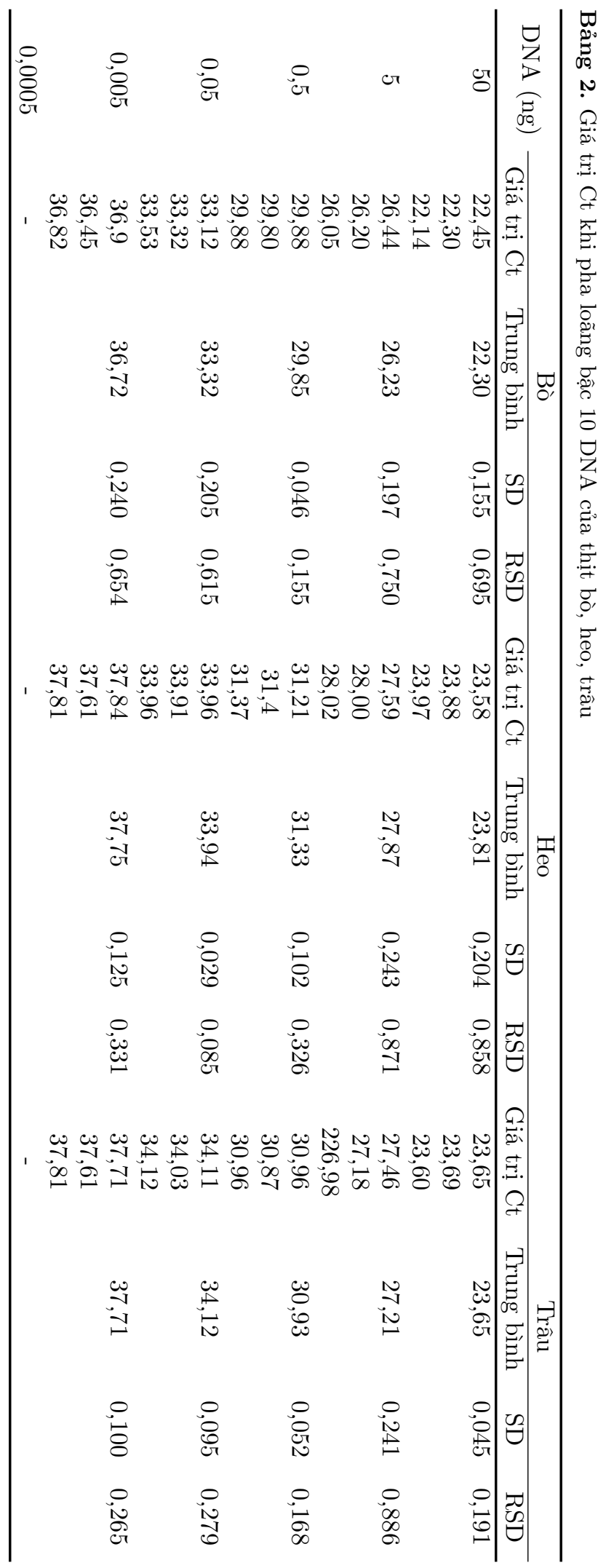



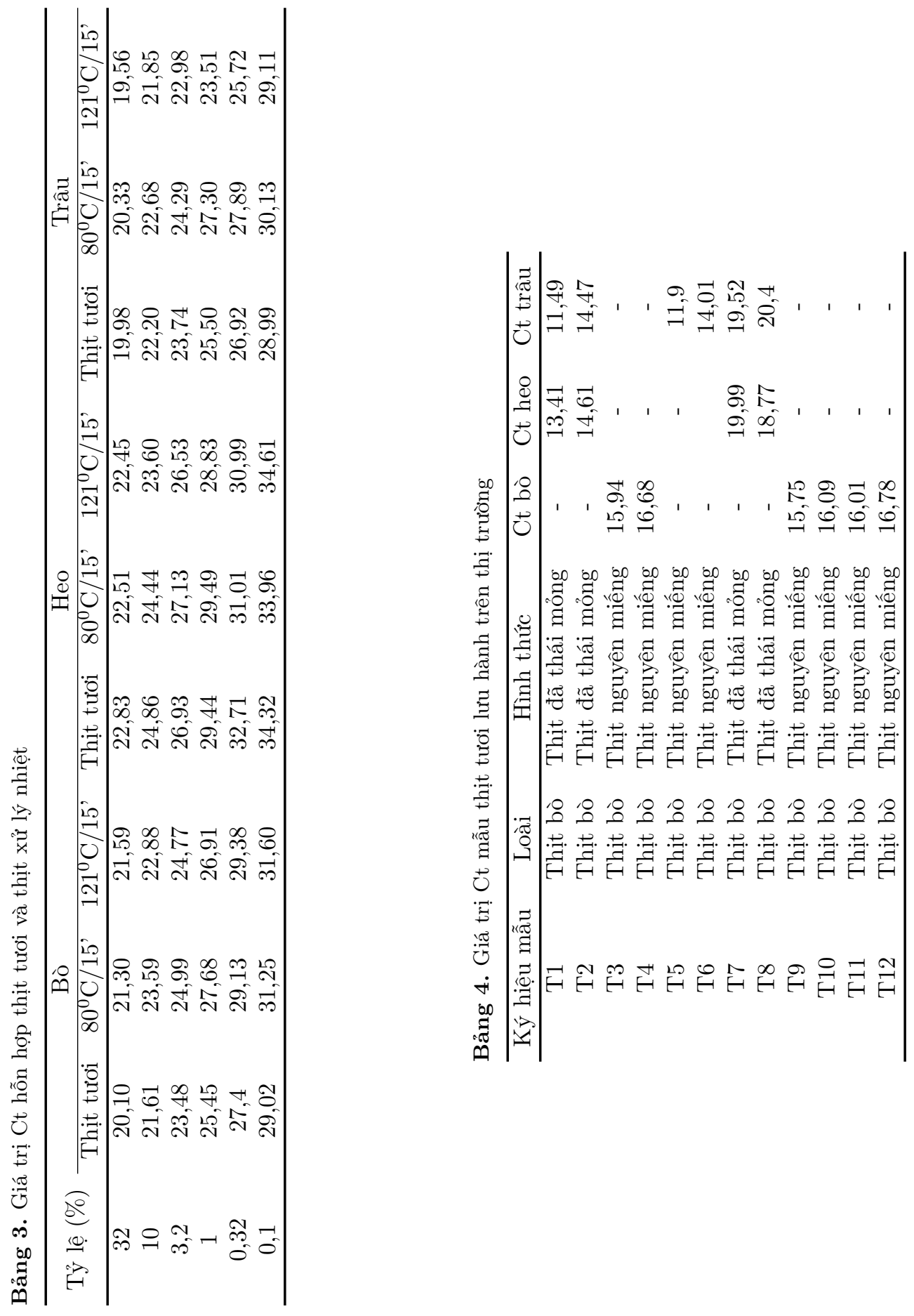
Bảng 5. Giá trị Ct mẫu xúc xích trên thị trường

\begin{tabular}{cclccc}
\hline Kí hiệu mẫu & Công ty & Thành phần trên nhãn & Bò & Heo & Trâu \\
\hline X1 & A & Heo, gà & - & 21,35 & 19,63 \\
X2 & A & Bò, heo & 21,31 & 22,79 & 18,47 \\
X3 & A & Heo, tôm & - & 17,71 & 16,56 \\
X4 & A & Heo, tôm & - & 17,36 & 17,82 \\
X5 & B & Gà, heo, đậu nành & - & 23,32 & 20,46 \\
X6 & B & Gà, heo, đậu nành & - & 19,24 & 21,51 \\
X7 & B & Bò, heo, gà & 24,05 & 26,68 & 20,97 \\
X8 & B & Bò, heo, gà & 22,85 & 21,62 & 20,76 \\
X9 & C & Heo, gà & - & 19,33 & - \\
X10 & C & Heo, gà, đậu nành & - & 20,04 & - \\
X11 & C & Bò, heo, gà, cá & 18,33 & 22,17 & - \\
X12 & C & Bò, heo, cá & 19,01 & 23,08 & - \\
\hline
\end{tabular}

Bảng 6. Giá trị $\mathrm{Ct}$ mẫu bò viên trên thị trường

\begin{tabular}{cclccc}
\hline Kí hiệu mẫu & Công ty & Thành phần trên nhãn & Bò & Heo & Trâu \\
\hline V1 & A & Bò, cá basa & 20,33 & - & 18,48 \\
V2 & A & Bò, cá basa & 17,95 & - & 16,51 \\
V3 & B & Bò, dậu nành & 23,15 & 22,36 & 18,99 \\
V4 & B & Bò, dậu nành & 22,15 & 19,38 & 18,72 \\
V5 & C & Bò, cá basa, gà & 22,1 & - & - \\
V6 & C & Bò, cá basa, gà & 23,46 & - & - \\
V7 & D & Bò, mỡ heo & 20,06 & 24,36 & 17,75 \\
V8 & D & Bò, mỡ heo & 17,44 & 19,16 & 16,36 \\
V9 & E & Bò, heo, gà & 21,16 & 20,03 & 18,91 \\
V10 & E & Bò, heo, gà & 20,59 & 20,57 & 19,05 \\
V11 & F & Bò, thịt heo & 20,16 & 22,03 & - \\
V12 & F & Bò, thịt heo & 21,08 & 22,78 & - \\
\hline
\end{tabular}

trâu có thể được thêm để tăng giá trị dinh dưỡng cũng như hương vị của sản phẩm. Mặt khác, giá trị kinh tế của trâu thấp hơn bò. Cho nên việc thêm thịt trâu vào xúc xích bò hoặc xúc xích bò heo để giảm giá thành sản xuất, tăng lợi nhuận.

\subsubsection{Mẫu bò viên}

Bò viên có giá cao hơn các loại thịt viên khác. Thịt viên sau khi xay nhỏ, chế biến, tẩm ướp gia vị khó có thể nhận biết được thành phần bằng cảm quan. Mười hai (12) mẫu bò viên từ 6 công ty được chọn để kiểm tra. Kết quả từ Bảng 6 cho thấy tất cả 12 mẫu đều được phát hiện có thịt bò trong sản phẩm. Tuy nhiên, hai mẫu bò viên công ty A đã phát hiện thêm thịt trâu trong sản phẩm. Đây là thành phần không công bố trên nhãn. Đối với mẫu công ty $\mathrm{B}$, heo và trâu là hai thành phần không có trên nhãn nhưng được phát hiện bằng multiplex real-time PCR. Tương tự, những mẫu của công ty $\mathrm{D}$ và $\mathrm{E}$ đã phát hiện được thịt trâu trong sản phẩm. Như vậy, chỉ có 04 trên 12 mẫu đúng về thành phần bò, heo, trâu công bố trong sản phẩm. Hai trong số 12 mẫu $(16,67 \%)$ hiện diện thêm thịt heo mà không được công bố trên nhãn; có 8 trên 12 mẫu $(66,67 \%)$ được thêm thịt trâu vào trong sản phẩm bò viên.

\section{Kết Luận}

Đã tối ưu quy trình multiplex real-time PCR phân biệt thịt bò, trâu, heo với độ đặc hiệu và độ tin cậy cao, giới hạn phát hiện thịt tươi (bò, trâu, heo) và thịt xử lý nhiệt $\left(80-120^{\circ} \mathrm{C} / 15\right.$ phút) là 0,1\% theo trọng lượng trong hỗn hợp hoặc 0,005 ng DNA/phản ứng. Ứng dụng multiplex real-time PCR để phát hiện mẫu thịt tươi nguyên miếng hoặc thái mỏng và một số sản phẩm thịt chế biến trên thị trường cho thấy có vấn đề gian lận giả thịt bò từ thịt heo và thịt trâu. 


\section{Tài Liệu Tham Khảo (References)}

Ali, M. E., Asing, Hamid, S. B. A., Razzak, M. A., Rashid, N. R. A., Al Amin, M., \& Mustafa, S. (2015). A suitable method to detect potential fraud of bringing Malayan box turtle (Cuora amboinensis) meat into the food chain. Food Additives \& Contaminants, Part A, 32(8), 1223-1233.

Ali, M. E., Razzak, M. A., \& Hamid, S. B. A. (2014). Multiplex PCR in species authentication: Probability and prospects review. Food Analytical Methods 7(10), 1933-1949.

Ayaz, Y., Ayaz N. D., \& Erol I. (2006). Detection of species in meat and meat products using enzymelinked immunosorbent assay. Journal of Muscle Foods $17(2), 214-220$.

Erwanto, Y., Zainal Abidin, M., Sugiyono, E. Y. P. M., \& Rohman, A. (2014). Identification of pork contamination in meatballs of Indonesia local market using polymerase chain reaction-restriction fragment length polymorphism (PCR-RFLP) analysis. Asian-Australasian Journal of Animal Sciences 27(10), 1487-1492.

Girish, P. S., Haunshi, S., Vaithiyanathan, S., Rajitha, R., \& Ramakrishna, C. (2013). A rapid method for authentication of buffalo (Bubalus bubalis) meat by alkaline lysis method of DNA extraction and species-specific polymerase chain reaction. Journal of Food Science and Technology 50(1), 141-146.

Hoang, L. (2016). All samples of fake beef originated from sow meat are contaminated with microorganisms. The Youth Newspaper. Retrieved February 17, 2016, from http://tuoitre.vn/tin/kinhte/20160217/tat-ca-mau-thit-heo-nai-gia-thit-bo-deunhiem-vi-sinh/1052863.html.

Jeanette, T. (2013). Chinese police seize more than $20,000 \mathrm{~kg}$ of fake beef. Retrieved September 20, 2013, from https://sg.news.yahoo.com/blogs/what-isbuzzing/chinese-police-seize-more-20-000kg-fake-beef035448883.html.
Koppel, R., Ruf, J., \& Rentsch, J. (2010). Multiplex realtime PCR for the detection and quantification of DNA from beef, pork, horse and sheep. European Food Research and Technology 232(1), 151-155.

Koppel, R., Ruf, J., Zimmerli, F., \& Breitenmoser, A. (2008). Multiplex real-time PCR for the detection and quantification of DNA from beef, pork, chicken and turkey. European Food Research and Technology 227(4), 1199-1203.

Koppel, R., Weibel, S., Ruf, J., Eugster, A., Beck, K., \& Rentsch, J. (2013). Interlaboratory validation of two multiplex quantitative real-time PCR methods to determine species DNA of cow, sheep and goat as a measure of milk proportions in cheese. European Food Research and Technology 236(1), 217-227.

Mane, B. G., Mendiratta, S. K., \& Tiwari, A. K. (2012). Beef specific polymerase chain reaction assay for authentication of meat and meat products. Food Control 28(2), 246-249.

NCVTV24 (News Center VTV24). (2016). No beef DNA from the 2 samples of beef meatballs of Viet Sin is detected. Retrieved July 12, 2016, from http://vtv.vn/chuyen-dong-24h/khong-tim-thay-adncua-bo-trong-2-mau-bo-vien-cua-viet-sin-201602.htm.

Pham, V. H. (2009). PCR and real-time PCR, basic problems and common applications. Ho Chi Minh City, Vietnam: Medical Publishing House.

Sakaridis, I., Ganopoulos, I., Argiriou, A., \& Tsaftaris, A. (2013). A fast and accurate method for controlling the correct labeling of products containing buffalo meat using high resolution melting (HRM) analysis. Meat Science 94(1), 84-88. 